
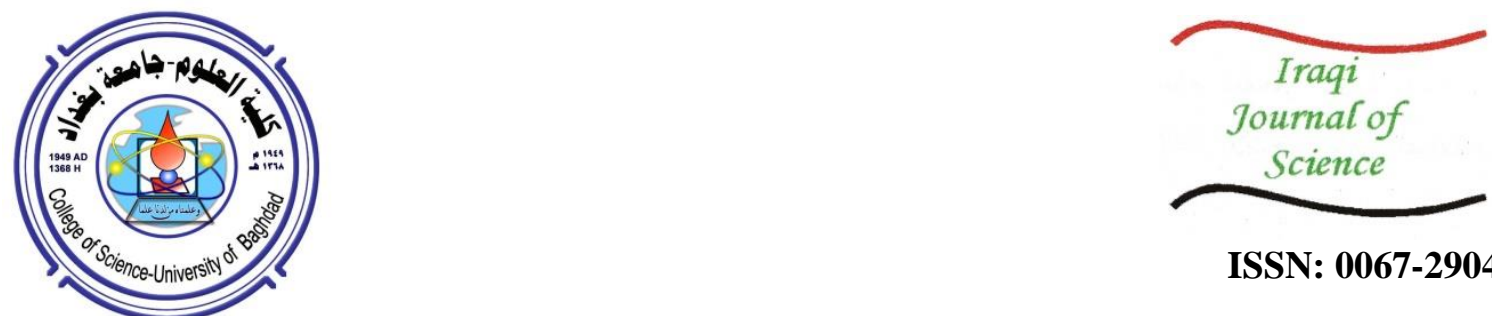

ISSN: 0067-2904

\title{
The Suitability of Tigris River Sediments from Tikrit, Northern Iraq, for Concrete Production and Road Construction Purposes
}

\author{
Mohanad Essa Khudhur \\ Natural Resources Research Center, University of Tikrit, Tikrit, Iraq \\ Received: 6/4/2020 \\ Accepted: 21/7/2020
}

\begin{abstract}
This study aims to assess the suitability of the sediments present in Tigris River, Tikrit city, northern Iraq for concrete production and road building purposes. Representative samples were collected from three selected stations at the study area using the channel modeling method. According to the grain size analysis, the sediments were classified as a type of poorly graded gravels (GP) depending on the unified soil classification system. The true specific gravity of the soil ranged between 2.28 and 2.568 . The chemical analysis of the study samples revealed that gypsum content ranged between 0.82 and $1.69 \%$. Total soluble salts ranged 2.45$3.87 \%$, the organic matter content ranged $0.14-0.76 \%$, and the $\mathrm{pH}$ value was between 7.73 and 7.38\%. The results of the Los Angeles Abrasion Test of selected samples showed weight loss ratios for the three stations (1,2, and 3) of 19.9, 20.7, and $17.2 \%$, respectively, while the maximum dry density values were 2.2739 , 2.1940 , and $2.2013 \mathrm{gm} / \mathrm{cm}^{3}$, respectively. The values of the Californian Bearing Ratio test (C.B.R) were 53, 65 and $106 \%$, respectively. After comparing the results with the standard values of ASTM for concrete and roads materials, it was found that the samples were suitable for these purposes.
\end{abstract}

Keywords: Los Angeles Abrasion Test; The Californian bearing ratio test; Road Purposes; Concrete.

\section{صلاحية ترسبات نهر دجلة في مدينة تكريت/شمالي العراق لاغراض الخرسانة والطرق}

$$
\begin{aligned}
& \text { مهند عيسى خضر } \\
& \text { مركز بحوث الموارد الطبيعية، جامعة تكريت، تكريت، العراق } \\
& \text { الخلاصة } \\
& \text { يهدف البحث الى دراسة صلاحية ترسبات نهر دجلة الحديثة في مدينة تكريت / شمال العراق لأعمال } \\
& \text { الخرسانة والطرق, تمت النمذجة من ثلاث محطات منتخبة من منطقة الدراسة بطريقة النمذجة القناتية ووفقا } \\
& \text { للتحليل الحجمي الحبيبي كانت الترسبات من النوع GP حسب التصنيف الموحد للتربة, كما تراوح الوزن }
\end{aligned}
$$

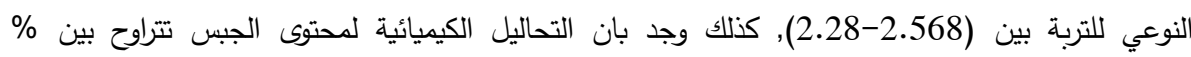

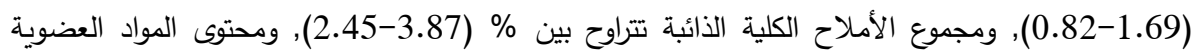

$$
\begin{aligned}
& \text { تتراوح بين \% (0.76-0.14), كما بلغت قيمة الأس الهيدروجيني بين \% (7.73-7.38) (2.38), كما أظهرت نتائج } \\
& \text { الفحص المختبري لفحص لوس انجلوس لنماذج منطقة الدراسة, نسبة فقدان الوزن لنموذج المحطة الأولى } \\
& \text { (\% 19.9) وللمحطة الثانية (\% 20.7) وللمحطة الثالثة (\% 17.2) وكانت قيم الكثافة الجافة العظىى } \\
& \text { للمحطات الثلاثة على التوالي هي (2.2739 و } 2.1940 \text { و 2013) غم/سم والتي تم الحصول عليها من }
\end{aligned}
$$




$$
\begin{aligned}
& \text { فحص الحدل المعدل. فيما كانت قيم فحص التحمل الكاليفورني (C.B.R) بحدود لنسبة حدل 95\% للمحطات } \\
& \text { الثلاثة على التوالي هي (53 و } 65 \text { و 106) ومن النتائج اعلاه نلاحظ ان نماذج منطقة الدراسة تصلح } \\
& \text { لاستخدامها في الأعمال الخرسانة والطرق. بعد مقارنتها مع مواصفات الجمعية الامريكية لاختبار المواد } \\
& \text { الخاصة بالخرسانة والطرق. (ASTM) }
\end{aligned}
$$

\section{Introduction}

A natural aggregate is a raw material that consists of rock grains, with a size range of 0.07-75 mm. It could be composed of small particles such as sand and large particles such as gravel. Naturally, these materials are formed as a result of erosion and weathering processes, producing sediments of rivers, valleys, slopes, and floodplains. Industrially, they are formed by the breakage of natural rocks extracted from quarries, e.g., by using crushers. The output will be different sizes of sand and gravel, which are called broken sand and gravel [1].

Aggregates constitute about $70-75 \%$ of the total volume of concrete mix, providing it with stability and resistance to external forces and weather conditions [2].

One of the most important justifications for the current study is the large-scale river dredging operations taking place on the Tigris River in the city of Tikrit by the Ministry of Water Resources / Directorate of Water Resources in Salah Al-Din Governorate. The estimated amount of river deposits that have been accumulated from the river during the first stage is around $6,00,000 \mathrm{~m}^{3}$, which implicates that approximately $5,000,000 \mathrm{~m}^{3}$ could be collected in the other stages. The deposits have been accumulated near the river without a well-studied mechanism to take advantage of them.

This study aims to show the suitability of river deposits at the study area for engineering uses, by conducting the engineering tests required for this purpose. These include grain size analysis, specific gravity, Los Angeles Abrasion Test, and Californian Bearing Ratio test, along with chemical tests of sediments (organic content, gypsum content, total soluble salts (TSS), and $\mathrm{pH}$ value).

\section{Location of the study area}

The study area is located in the province of Salahaddin, Tikrit district, northern Iraq, with longitudes of $\left(34^{\circ} 35^{\prime} 30^{\prime \prime}-34^{\circ} 37^{\prime} 00^{\prime \prime} \mathrm{N}\right)$ and latitudes of $\left(43^{\circ} 41^{\prime} 00^{\prime \prime}-43^{\circ} 42^{\prime} 00^{\prime \prime} \mathrm{E}\right)$, as shown in Figure-1.

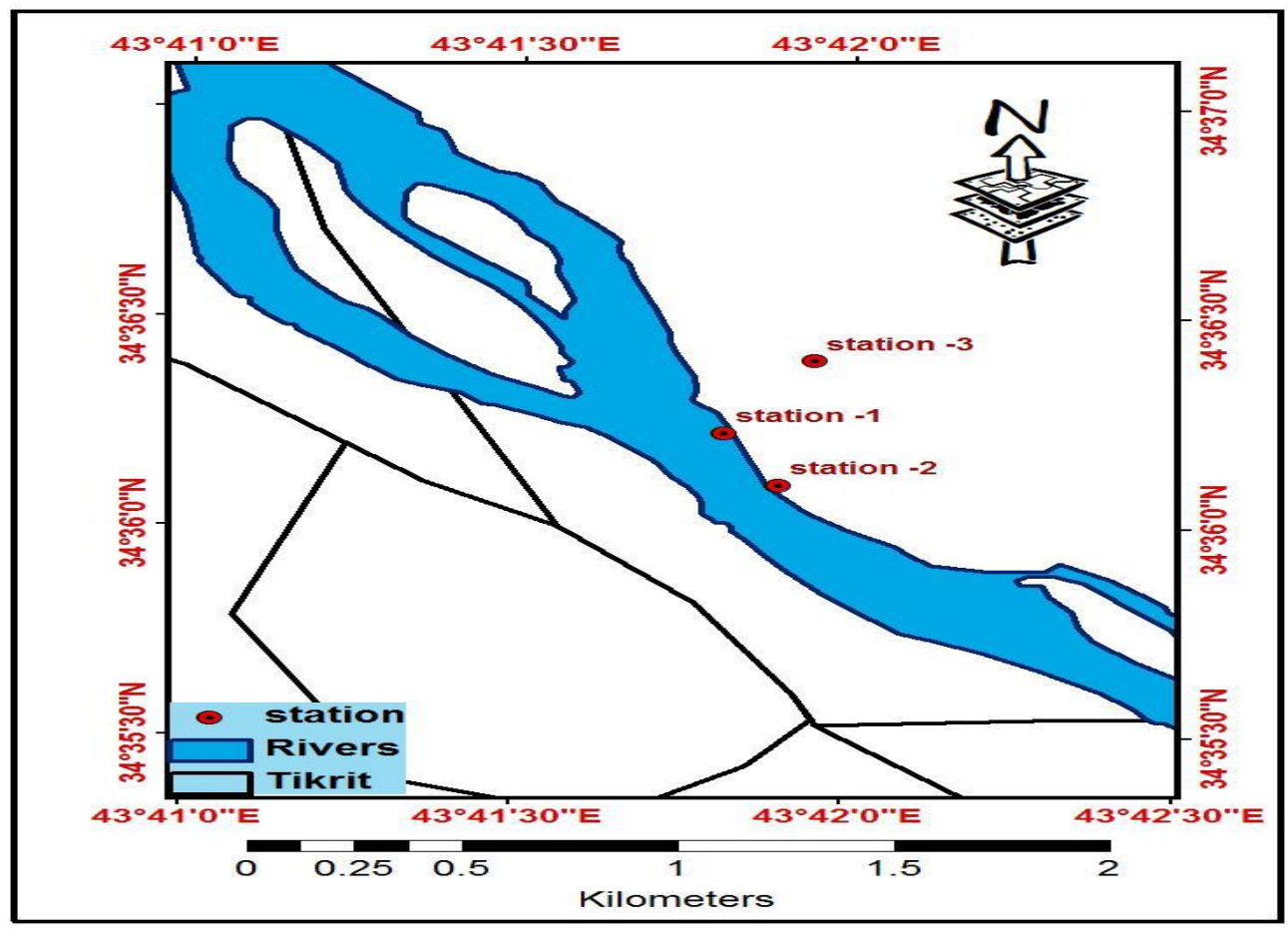

Figure 1- Location map of the study area

\section{Materials and Methodology}

Samples were taken from three elected stations from the Tigris River sediments in the study area. A 
geographic information system (GPS) device was used to locate the stations. Laboratory work included conducting physical, chemical, and engineering tests.

\section{Laboratory tests}

\section{Grain size analysis}

This examination was conducted according to the American standard [3] at the Geology Workshop, Department of Applied Geology, College of Science, Tikrit University.

\section{Elongation Coefficient}

The percentage of grains that largest dimensions (length) increases by 1.8 from their nominal size (the general average length of the grains) to the total sample weight and depending on standard sieves the remaining longitudinal grains are weighed on each sieve and collected and divided on the total sample weight as in Equation No. (1) [4].

$$
\text { Elongation Coefficient }=\frac{\text { Weight of grains that largest increases by } 21.6 \mathrm{~mm}}{\text { total sample weight }} * 100
$$

\section{Flakiness Index}

This index reflects the percentage of grains whose smallest dimensions (thickness) is 0.6, i.e. less than their nominal size, which represents the general average thickness of the granules) to the total sample weight. Depending on standard sieves, the flat granules passing through each sieve are collected, weighed, and the result is divided by the total sample weight, as in Equation No. (2) [4].

$$
\text { Flakiness Index }=\frac{\text { Weight of grains that largest less by } 7.2 \mathrm{~mm}}{\text { total sample weight }} * 100
$$

\section{Grain Shape}

The grain shape is defined as the forms that are shaped by the influence of various natural factors such as weathering and erosion. It is a relative measure for estimating the extent of granules containing angles and sharp edges [2].

\section{Specific gravity}

This measure is expressed as the ratio of weight or mass of a certain volume of a substance to that of the same volume of water at a specific temperature $[5,6]$.

\section{Los Angeles Abrasion Test}

This index describes the amount of measuring the resistance extent of coarse aggregate by evaluating the wear and friction through the measuring the value of the changes in the exterior surface. The examination was conducted according to the American standard classification $[7,8]$, as in Equation No. (3).

Abr. $=$ Los Angeles abrasion index

$$
\text { Abr. } \%=\{(A-B) / A\} \times 100
$$

$\mathrm{A}=$ Sample weight before test $(\mathrm{g})$

$\mathrm{B}=$ Dry sample weight $(\mathrm{g})$ remaining on the sieve $(1.7 \mathrm{~mm})$ after the test.

\section{Compaction Test}

Compaction is defined as the process by which soil particles are rearranged by using mechanical means to reduce soil porosity and increase dry density. The wet density, moisture content, and dry soil density were calculated as in equation 4 :

$=$ Wet density of soil $\left(\mathrm{gm} / \mathrm{cm}^{3}\right)$. $\rho$ wet

$$
\rho \text { wet }=\frac{\mathrm{m} 2-\mathrm{m} 1}{v}
$$

(gm) Weight of the base with the mold $m 1=$

$(\mathrm{gm}) .=$ Soil weight $m 2$

Mold volume $\left(\mathrm{cm}^{3}\right) \cdot v=$

\section{Californian Bearing Ratio Test}

This is a penetration test to assess the susceptibility and tolerance of soil and core materials. The test was performed according to American standards [9].

\section{Chemical Analysis \\ Gypsum content}

Gypsum is calcium sulfate dehydrate $\left(\mathrm{CaSO}_{4} \cdot 2 \mathrm{H}_{2} \mathrm{O}\right)$ and has a specific weight of 2.32. It has a significant and clear effect on the physical properties of aggregates containing gypsum in a large amount. It has been shown [10] that gypsum soil is one of the most complex soils, which is used as a basis or in building. It is strong to a large extent and has good properties when it is dry, but the 
problems arise when it is exposed to water through rain, high level groundwater, or other sources. This examination was performed according to previously published specifications [11].

\section{Organic Materials}

These materials result from the decomposition of organic materials represented by plant and animal remains and other organic residues that are present as impurities [2]. The presence of organic material causes the permeability of the soil and the occurrence of subsidence in the organic soil when soil is dried, due to shrinkage as well as high compressibility [12]. This examination was performed according to earlier published specifications [11].

\section{pH Value}

The $\mathrm{pH}$ value expresses the alkalinity or acidic function which represents the negative logarithm of the molar concentration of the hydrogen ion. Therefore, the $\mathrm{pH}$ of the soil is measured by the hydrogen ion concentration $\left(\mathrm{H}^{+}\right)$as it is measured from the soil solution [13].

\section{Total suspended salts}

It is the sum of salts that have the ability to dissolve in water to the weight of aggregates. The degree of solubility varies according to the nature of salts. Chlorides salts are generally easier to dissolve than sulfates and carbonates, which are considered harmful substances that are found in the aggregates [14].

\section{Results and discussion}

\section{Grain size analysis}

The results of the grain size analysis of the three stations elected from the study area are shown in Table-1. High ratios of gravel in different sizes were found at the three stations, with values ranging 57 $-67 \%$. The sand ratio was lower than that of gravel, whereas the fine grains showed the lower ratios. Figures- 2, 3, and 4 show the results of the grain size analysis of the sediments of the study area.

Table 1- Classification of soil for the samples of the study area

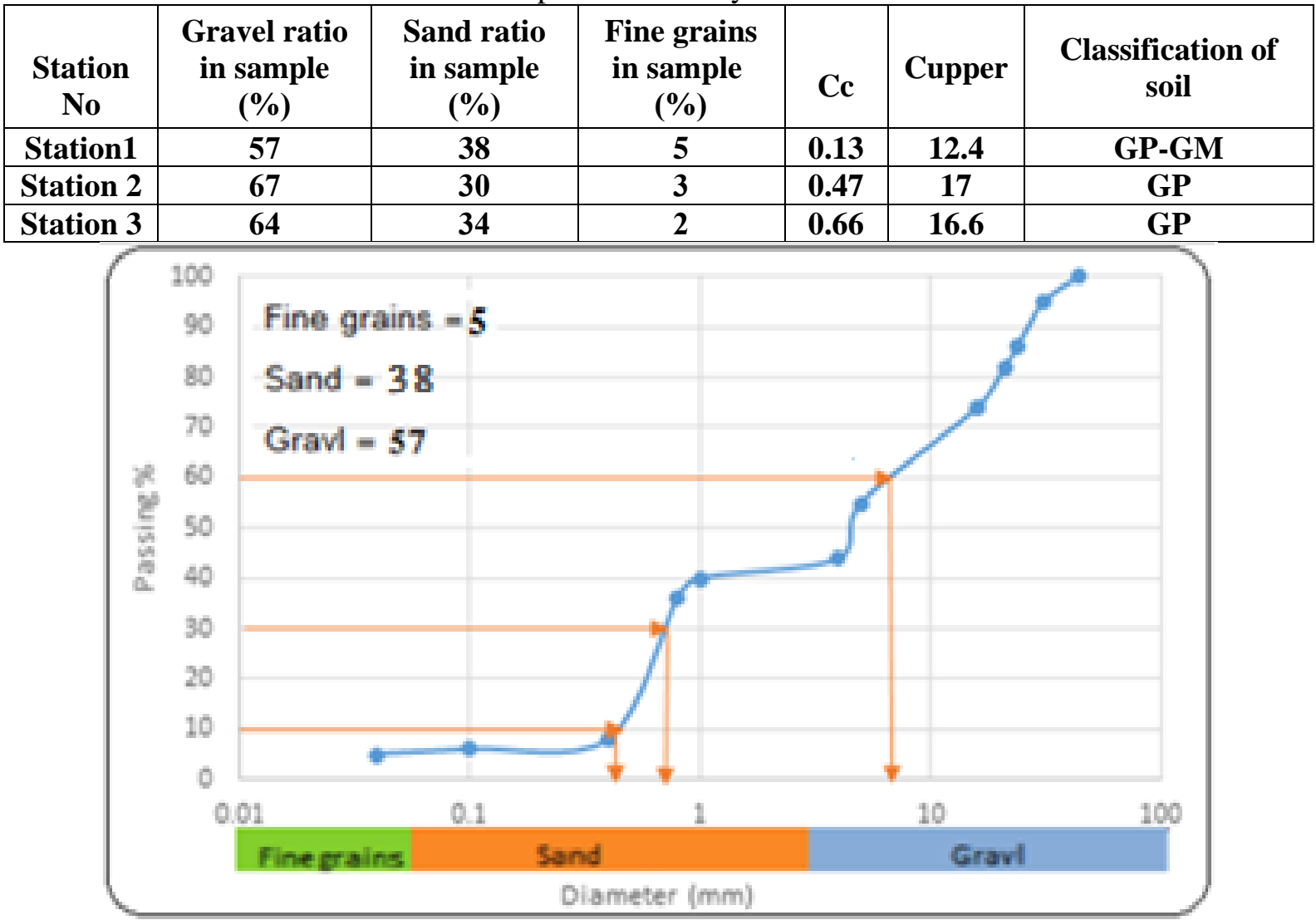

Figure 2-Grain size analysis of deposits in station 1 

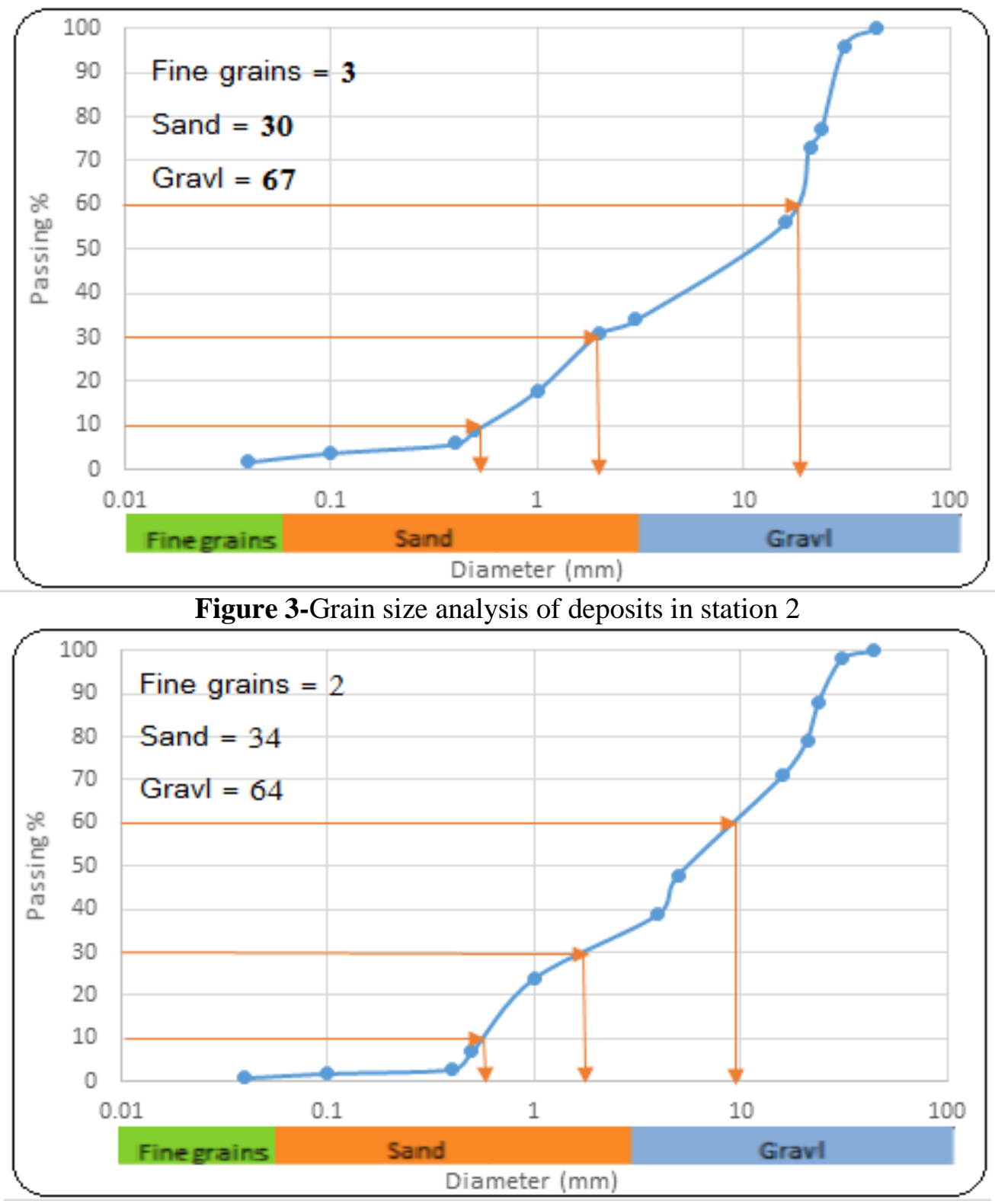

Figure 4-Grain size analysis of deposits in station 3.

\section{Elongation coefficient}

The test results of the elongation coefficient values for the three samples are shown in Table-2. The values are consistent with those of the British international classification, showing less than $50 \%$ of natural aggregates (stones) and $40 \%$ of broken aggregates.

Table 2-Elongation coefficient values for the samples of the study area.

\begin{tabular}{|c|c|}
\hline Station & Elongation coefficient \\
\hline Station 1 & 9.11 \\
\hline Station 2 & $\mathbf{6 . 9 2}$ \\
\hline Station 3 & $\mathbf{7 . 8 3}$ \\
\hline
\end{tabular}

\section{Flakiness Index}

The test results of the flakiness index for the three satiation are listed in Table-3, which were within the recommended requirements for the purposes of the study according to the British international classification, having more than $50 \%$ of natural aggregates (stones) and $40 \%$ of broken aggregates. 
Table 3- Flakiness index values for the sample of the study area

\begin{tabular}{|c|c|}
\hline Station & Flakiness Index \\
\hline Station 1 & 4.27 \\
\hline Station 2 & 2.69 \\
\hline Station 3 & 3.41 \\
\hline
\end{tabular}

\section{Grain shape}

This study showed that the grain shapes of the stones are different, including rounded, semirounded and occasionally sub-angular shapes. The rounded grains constituted $21-29 \%$ of the total content, while the range for the semi rounded grains was $23-34, \%$, for the sub-angular grains was 24 $-29 \%$, and for the angular grains was $8-13 \%$. Therefore, the samples were within the recommended requirements for the purposes of the study according to the British international classification, having more than $50 \%$ of natural aggregates (stones) and $40 \%$ of broken aggregates..

\section{Specific gravity}

The specific gravity values at the three sampling stations are shown in Table-4. The entire specific gravity values for all the samples reflected compliance with the allowed limits according to the American classification.

Table 4-Results of the specific gravity for the sample of the study area

\begin{tabular}{|c|c|c|c|}
\hline Station & $\begin{array}{c}\text { True specific gravity of coarse } \\
\text { aggregates }\end{array}$ & $\begin{array}{c}\text { Absorption ratio } \\
(\%)\end{array}$ & $\begin{array}{c}\text { Specific gravity of fine } \\
\text { aggregates }\end{array}$ \\
\hline Station 1 & $\mathbf{2 . 2 8}$ & $\mathbf{0 . 5 9}$ & 2.63 \\
\hline Station 2 & $\mathbf{2 . 3 1 1}$ & $\mathbf{0 . 4 4}$ & 2.64 \\
\hline Station 3 & 2.568 & $\mathbf{0 . 1 6}$ & 2.67 \\
\hline
\end{tabular}

Los Angeles Abrasion Test

The results of the laboratory tests of Los Angeles Abrasion test are listed in Table-5, showing suitability for usage for concrete production purposes. The lower limit of the missing weight for concrete and roads purposes is 35\%, according to the American classification [7].

Table 5-Results of Los Angeles abrasion test for the selected stations.

\begin{tabular}{|c|c|}
\hline Station & Abrasion ratio (\%) \\
\hline Station 1 & 19.9 \\
\hline Station 2 & 20.7 \\
\hline Station 3 & 17.2 \\
\hline
\end{tabular}

\section{Compaction test}

The results of the laboratory examination of the maximum dry density based on the compaction test for the three samples are shown in Table-6. Figures- $(5,6$, and 7) show the relation between the dry density and the moisture content of the samples from the three stations.

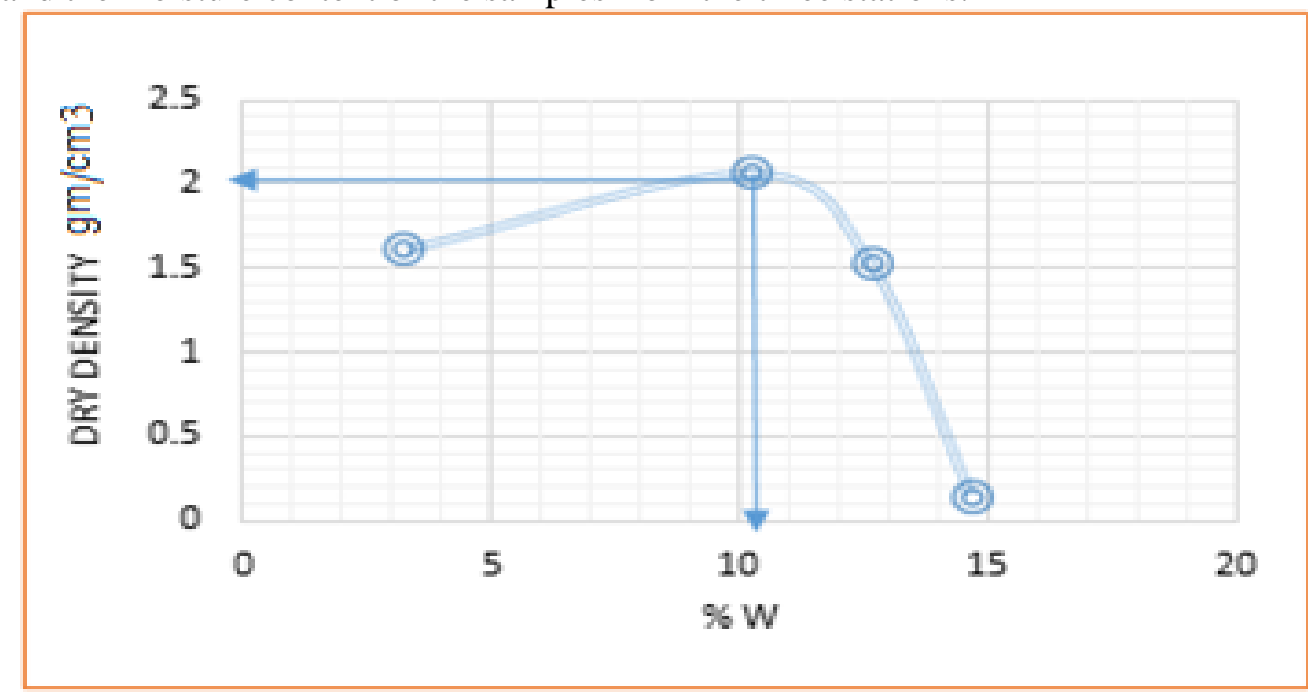

Figure 5-The relationship between the dry density and moisture content for the first station. 


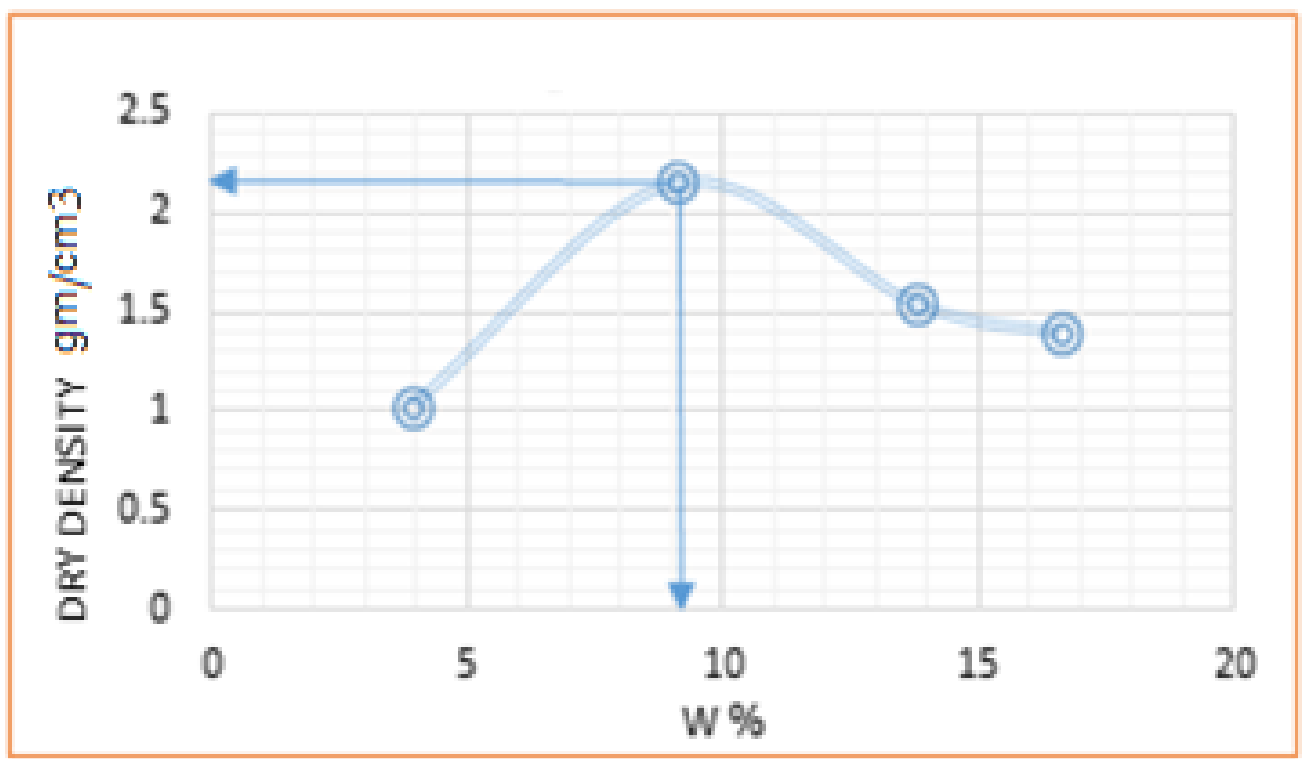

Figure 6-The relationship between the dry density and moisture content for the second station.

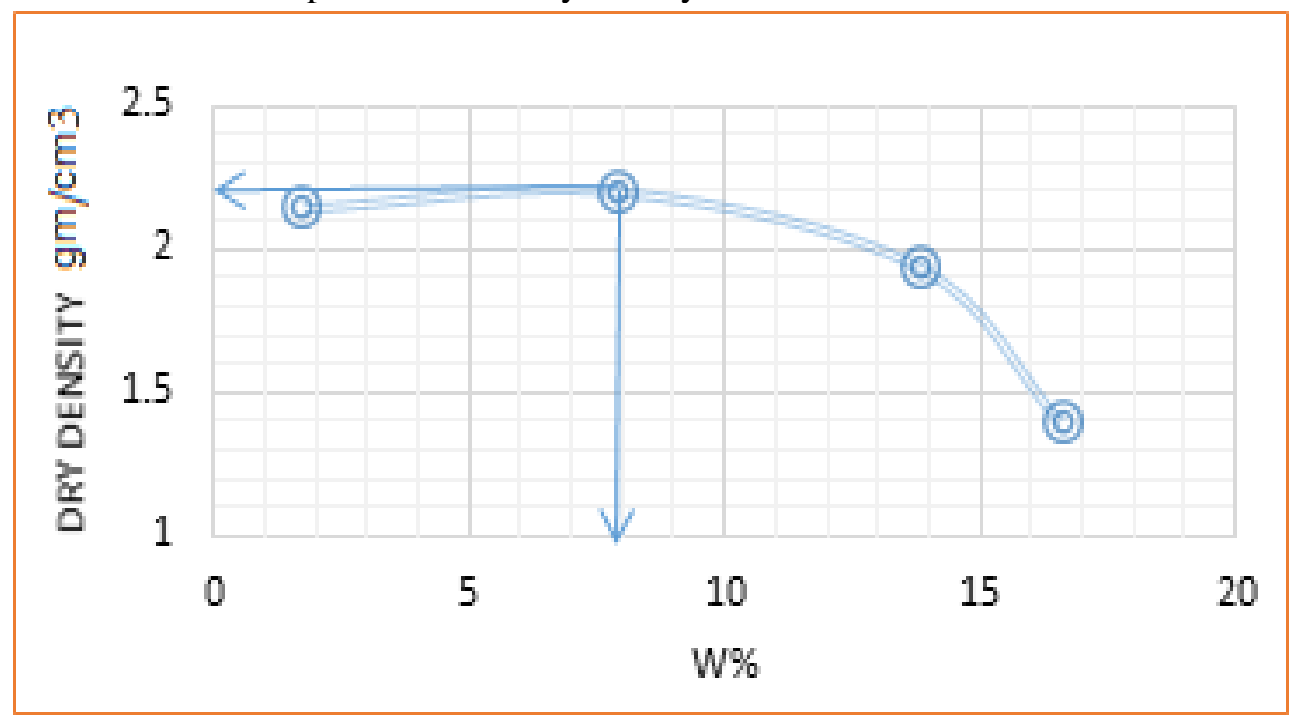

Figure 7-The relationship between the dry density and moisture content for the third station.

Table 6-The results of compaction test for the samples of the study area

\begin{tabular}{|c|c|c|}
\hline Station & $\begin{array}{c}\text { Optimum moisture } \\
\text { content \% }\end{array}$ & $\begin{array}{c}\text { Maximum dry } \\
\text { density }(\mathbf{g m} / \mathbf{c m 3})\end{array}$ \\
\hline Station 1 & $\mathbf{1 0 . 2 5 7}$ & $\mathbf{2 . 2 7 3 9}$ \\
\hline Station 2 & $\mathbf{9 . 3 1 9 6}$ & $\mathbf{2 . 1 9 4 0}$ \\
\hline Station 3 & $\mathbf{7 . 9 6 9 7}$ & $\mathbf{2 . 2 0 1 3}$ \\
\hline
\end{tabular}

\section{Californian bearing ratio test}

The results of the Californian bearing test showed that the values of C.B.R for $95 \%$ of dry density are 106, 53, and 65 for stations 1,2 and 3, respectively. The load penetration curves for the samples are shown in Figures- 8, 9, and 10. Then, the stress of the penetration values were found to be 2.5 and 5.0. C.B.R was calculated by using the bellow equation [9].

$$
C B R \%=\frac{\text { Measurd force }}{\text { standard force }} \times 100 \%
$$




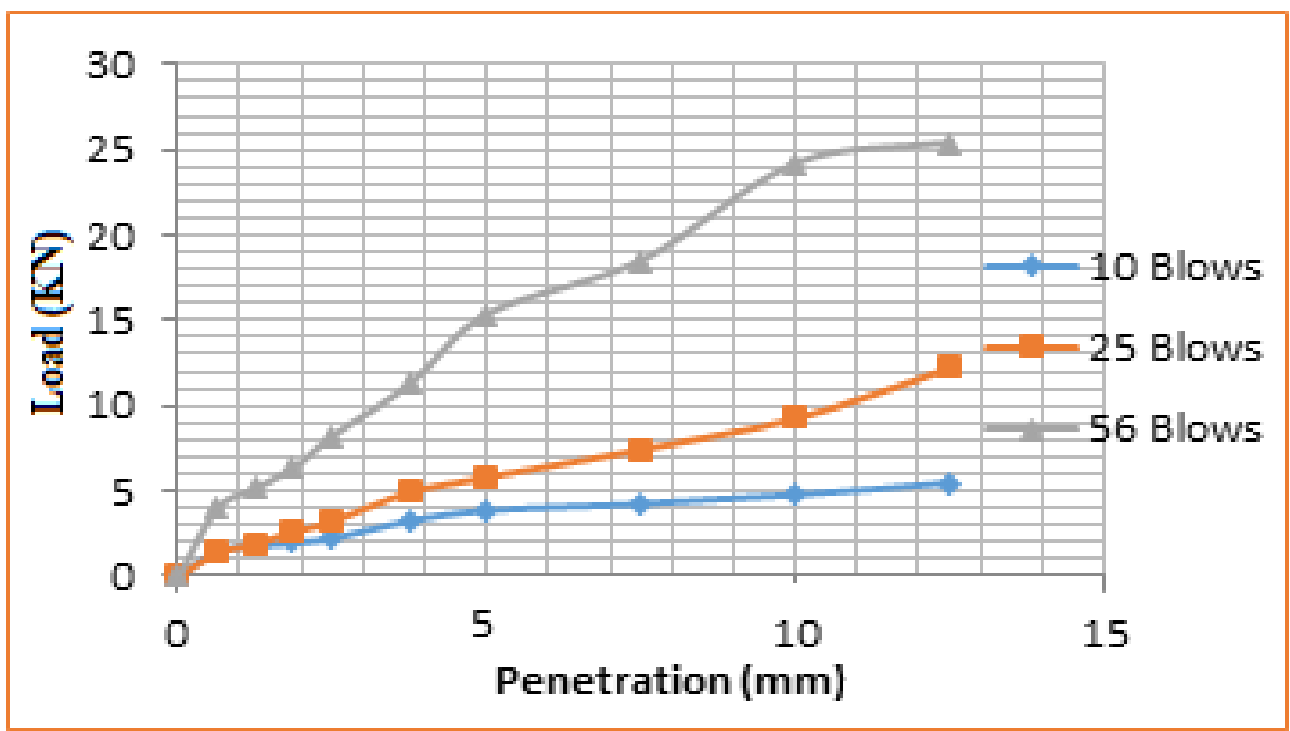

Figure 8-The relation between the penetration and loading for the first station.

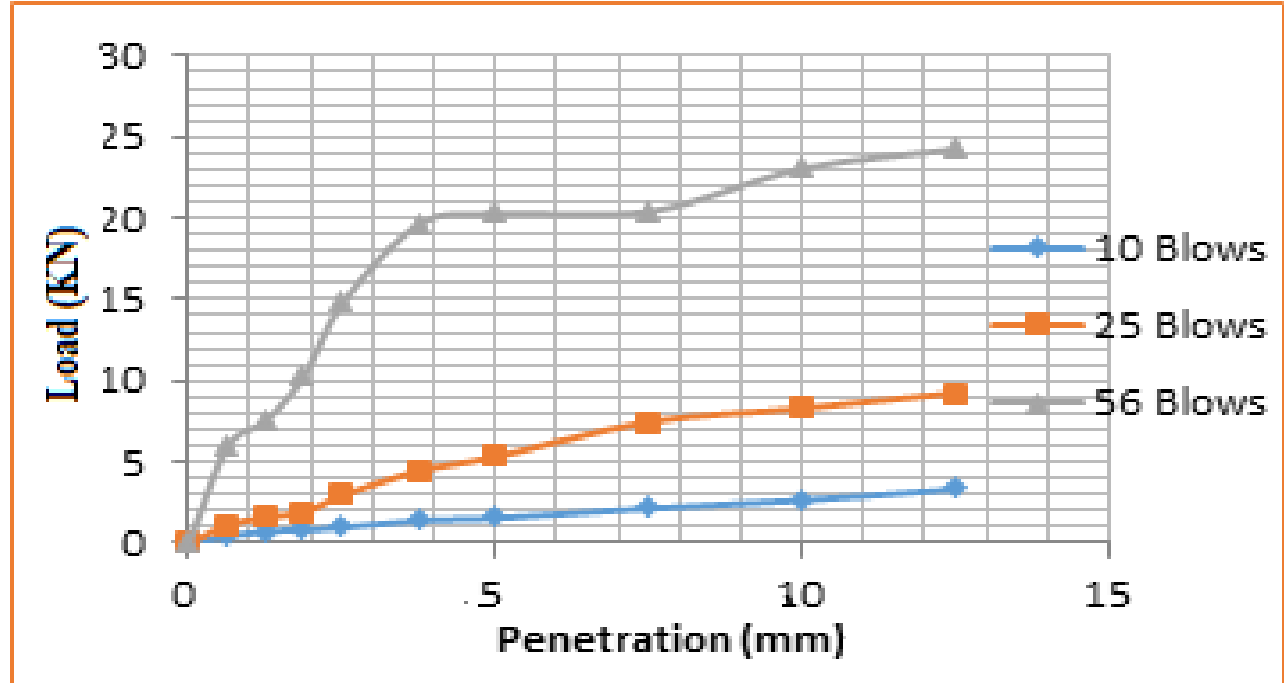

Figure 9-The relation between the penetration and loading for the second station.

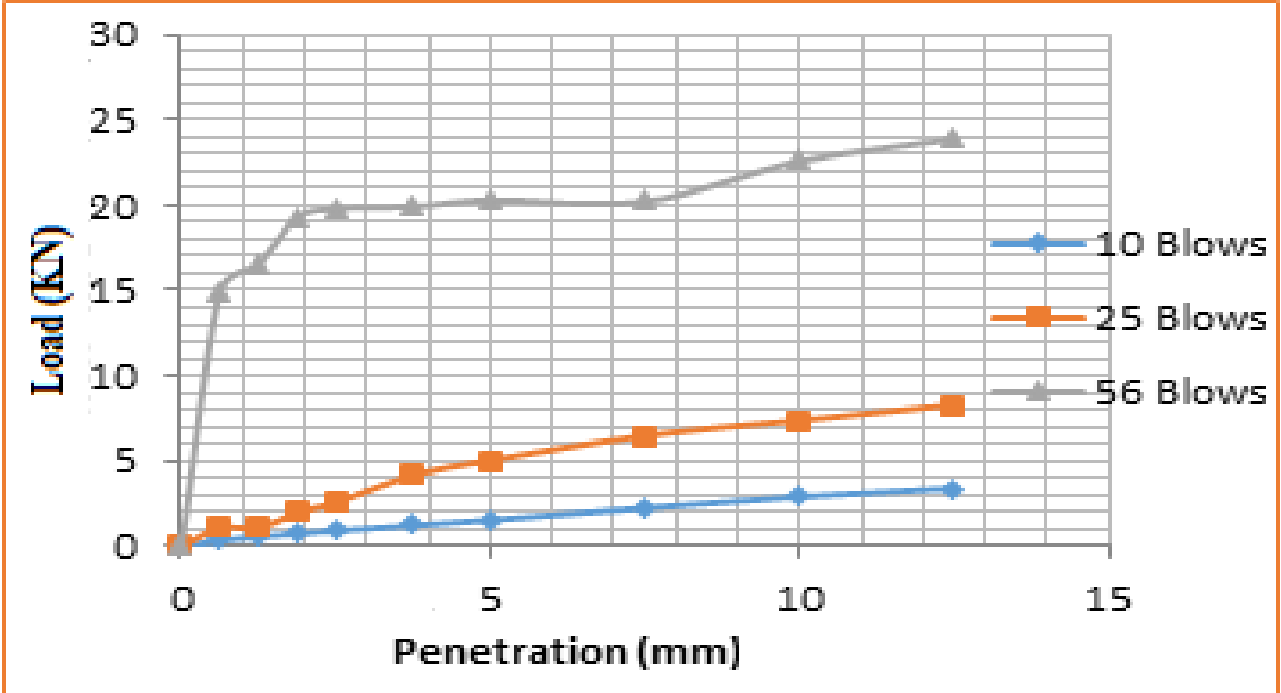

Figure 10-The relation between the penetration and loading for the third station.

Then, a relation between the dry density and the Californian bearing ratio for the samples of the studied stations could be drawn, as illustrated in Figures-(11, 12, and 13). The C.B.R value for the 
study area stations was found to be $95 \%$ at the compaction ratio from the Maximum dry density while the swelling soil was between 0.0021 and 0.0232 , as shown in Table-7.

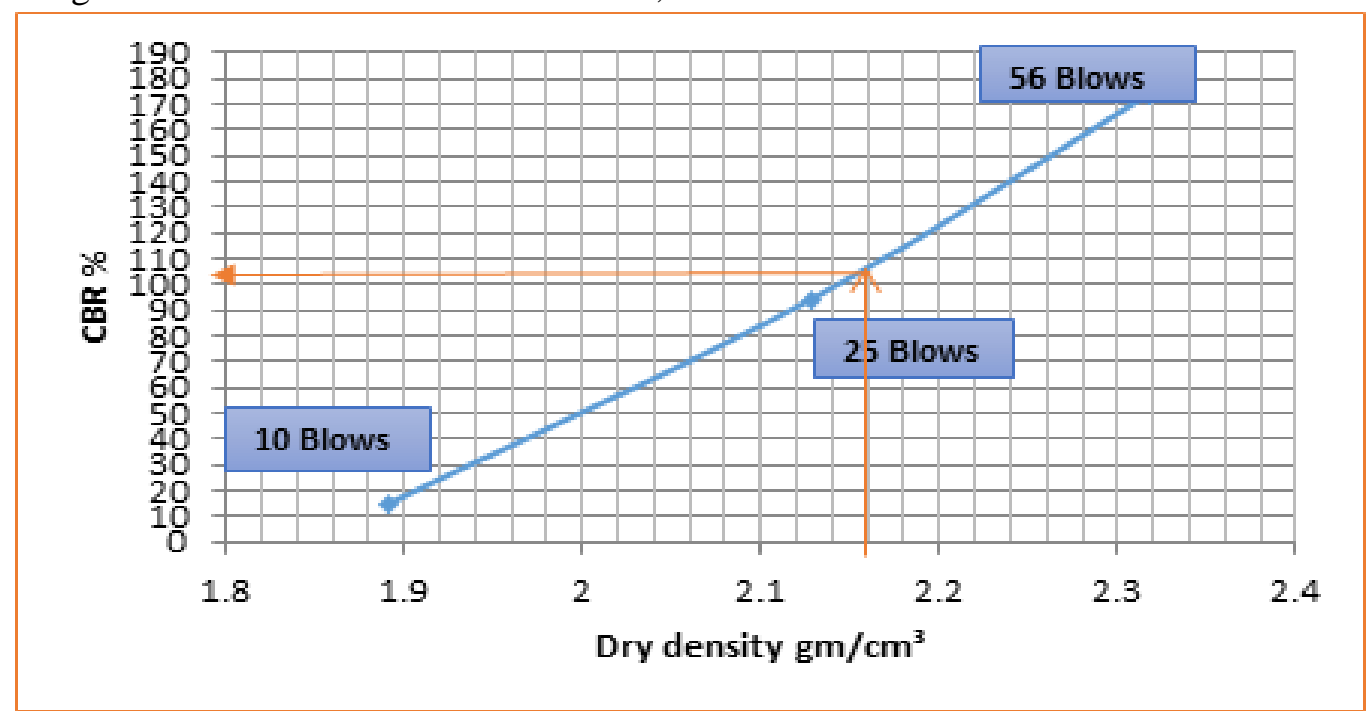

Figure 11-The relation between the dry density and C.B.R 5.0 for the first station.

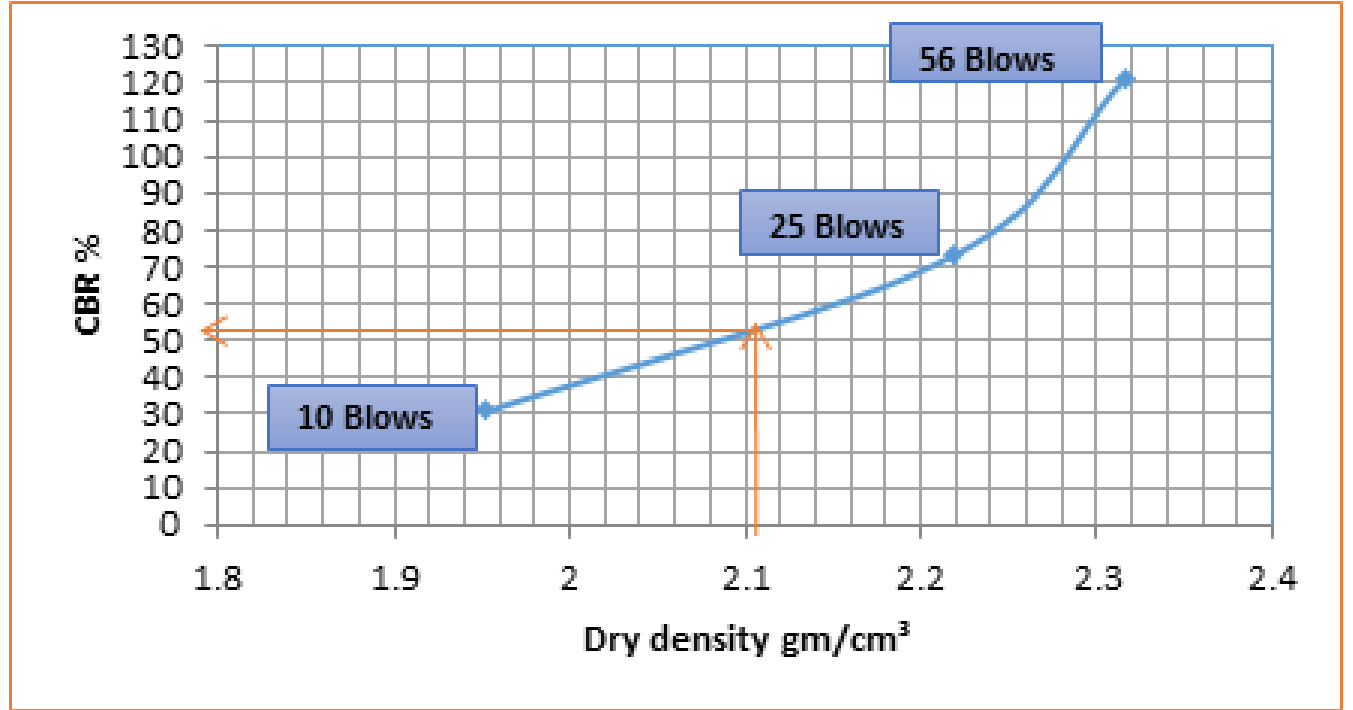

Figure 12-The relation between the dry density and C.B.R 5.0 for the second station.

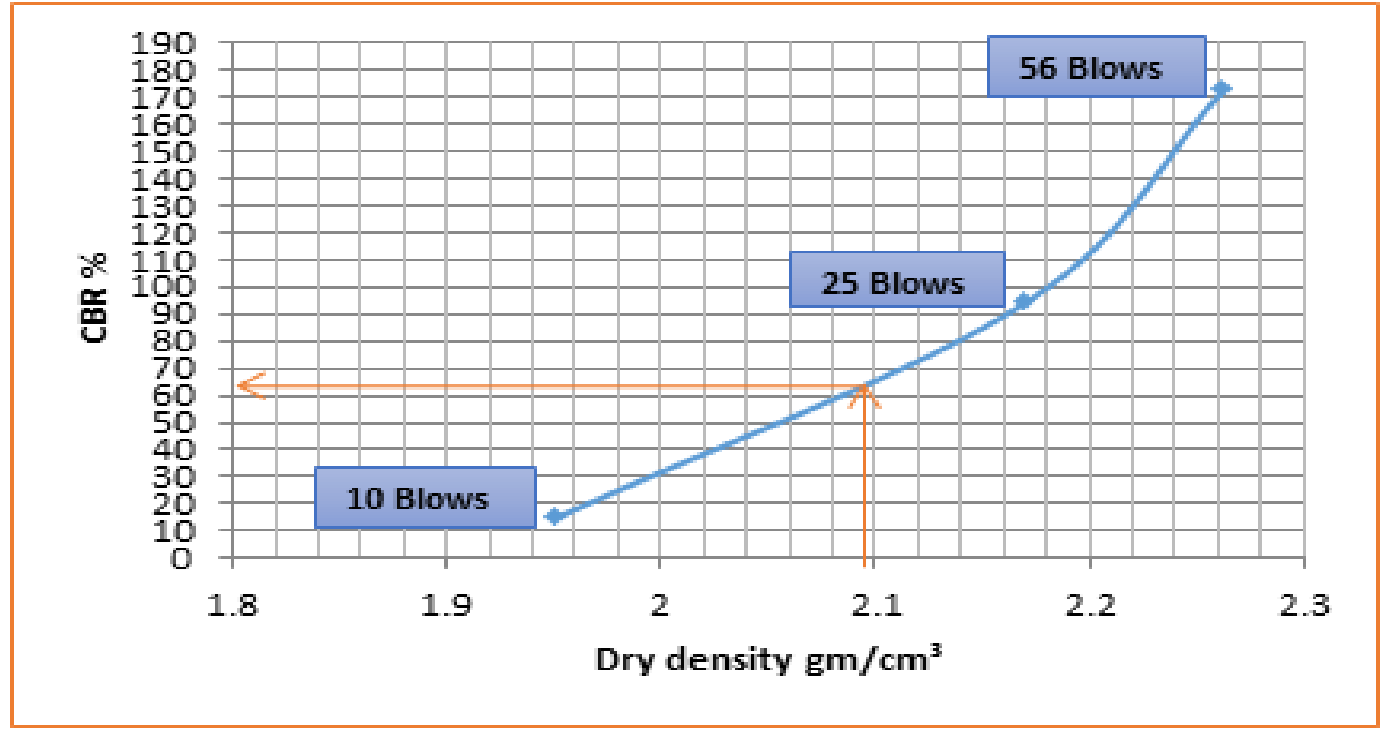

Figure 13- The relation between the dry density and C.B.R 5.0 for the third station. 
Table7-Test results of C.B.R for the selected stations.

\begin{tabular}{|c|c|c|c|c|c|c|}
\hline Station & $\begin{array}{l}\text { Number of } \\
\text { blood }\end{array}$ & $\begin{array}{c}\text { C.B.R\% } \\
(2.5)\end{array}$ & $\begin{array}{c}\text { C.B.R\% } \\
(\mathbf{5 . 0 )}\end{array}$ & $\begin{array}{c}\text { from dry } \\
\text { density } \% 95\end{array}$ & $\begin{array}{c}\text { C.B.R } \\
\% 995\end{array}$ & Swelling \\
\hline \multirow{3}{*}{ Station 1} & 10 & 19.3 & 27.5 & \multirow{3}{*}{2.1603} & \multirow{3}{*}{106} & 0.0021 \\
\hline & 25 & 38.7 & 52.1 & & & 0.0225 \\
\hline & 56 & 41.6 & 79.8 & & & 0.0212 \\
\hline \multirow{3}{*}{ Station 2} & 10 & 28.7 & 31.2 & \multirow{3}{*}{2.0863} & \multirow{3}{*}{53} & 0.0172 \\
\hline & 25 & 34.1 & 43.6 & & & 0.0193 \\
\hline & 56 & 51.9 & 58.4 & & & 0.0232 \\
\hline \multirow{3}{*}{ Station 3} & 10 & 13.5 & 15 & \multirow{3}{*}{2.1026} & \multirow{3}{*}{65} & 0.0021 \\
\hline & 25 & 74.7 & 44.3 & & & 0.0024 \\
\hline & 56 & 173.2 & 134.4 & & & 0.0121 \\
\hline
\end{tabular}

\section{Gypsum content}

The results of the soil samples test for the study area showed that the ratio of the gypsum was between 0.82 and $1.69 \%$, as shown in Table- 8 . This soil is considered to have a low content of gypsum because the samples were taken from the current river and are hence exposed to washing. So, the results of the three stations are compatible with the requirements of the gypsum ratio, that is not accede than (10.75\%) according to the British standard classification, [11]. for the concrete purposes and roads.

\section{Organic materials content}

The ratio of organic materials content in the studied samples was between 0.14 and $0.76 \%$, as shown in table 8 . Therefore, the results of the three stations are compatible with the requirements of concrete and road tests, according to the British standard classification [11], that is not exceeding a level of organic materials content higher than $2 \%$. An organic materials ratio higher than $1 \%$ is considered high since issues can be caused to soil strength if the soil is saturated with water and its clay content is high [15].

\section{pH Value}

The $\mathrm{pH}$ ranged was between 7.38 and $7.73 \%$, as shown in Table-8. Thus, the samples of the study area were equilibrium alkali, which is ineffective on uses for concrete and roads.

\section{Total suspended salts}

T.S.S was measured for the samples of the study area and the results ranged between 2.45 and 3.87 . The maximum ratio was at the second station while the minimum ratio was at the third station. Therefore, the samples were considered as compliant with the requirements of less than $10 \%$ for the concrete and roads purposes according to Earth Manual [16], as shown in Table-8.

Table 8-The Results of chemical tests for the selected stations

\begin{tabular}{|c|c|c|c|c|}
\hline Station & $\begin{array}{c}\text { Gypsum content } \\
\text { \% }\end{array}$ & $\begin{array}{c}\text { Organic materials } \\
\text { content \% }\end{array}$ & pH Value \% & T.S.S mg/L \\
\hline Station.1 & $\mathbf{1 . 6 9}$ & $\mathbf{0 . 3 8}$ & 7.61 & $\mathbf{3 . 0 2}$ \\
\hline Station.2 & $\mathbf{0 . 8 2}$ & $\mathbf{0 . 1 4}$ & 7.73 & $\mathbf{2 . 4 5}$ \\
\hline Station.3 & $\mathbf{1 . 2 7}$ & $\mathbf{0 . 7 6}$ & 7.38 & 3.87 \\
\hline
\end{tabular}

\section{Conclusions}

1. Different values of specific weight are indicative of the difference in mineral composition, as these deposits have different sources.

2. The sediments in the study area are of poor graded gravel (GP) with sand and a small percentage of grains, indicating that their sources are different.

3. The values of the maximum dry density ranged between 2.2739 and $2.1940 \mathrm{~g} / \mathrm{cm}^{3}$ and the optimum moisture content was between (7.9697and 10.257) \%. 
4. The results of Californian Bearing Ratio Test for $2.5 \mathrm{~mm}$ penetration ranged 13.5-173.2, while the range for $5 \mathrm{~mm}$ penetration was $15-134.4$ and the range at $95 \%$ of the dry density was $53-106$.

5. The gypsum and organic matter contents are low as a result of washing, as the sediments are taken from the river channel.

6. The required tests for the river sediments in Tigris river has noted that the sediments could be used for the concrete and roads purposes, according to standard specifications.

\section{References}

1. Miliutenko, S. 2009. Aggregate provision and sustainability issues in selected European cities around the Baltic ea. MSc. thesis University of Stockholm, Sweden pp 82.

2. Neville, A.M. and Brooks, J.J. 2010. Concrete Technology, $2^{\text {nd }}$ Edition, England, pp 442.

3. ASTM, D 422-63. 2004. Standard Test Method for Particle-Size Analysis of Soils.

4. B.S. 812, 1990. Method for determination of particles shape. Elongation Index of coarse aggregate. London, UK.

5. Bodó, B. and Jones, C. 2013. Introduction to soil mechanics, U.S.A, John Wiley \& Sons, Ltd, pp 608.

6. ASTM -C, 127-01. 2004. Standard Test Method for Relative Density (Specific Gravity) and Absorption of Coarse Aggregate Volume 4, p 1-5.

7. ASTM- C, 131 -96. 2004. Standard Test Method for Resistance to Degradation of Small -Size Coarse Aggregate by Abrasion and Impact in the Los Angeles Machine, Volume 4, p. 1-4.

8. ASTM, D1557-02E, 2003. Standard Test Methods for Laboratory Compaction Characteristics of Soil Using Modified Effort. Designation D1557-02. Approved November 10, 2002, published January 2003.

9. ASTM, D-1883 - 99, 2004. Standard Test Method for CBR (California Bearing Ratio) of Laboratory-Compacted Soils, p. 1-8.

10. Ahmad, F., Said, M.A.M. and Najah, L. 2012. Effect of Leaching and Gypsum Content on Properties of Gypseous Soil, International Journal of Scientific and Research Publications,2(9): 15.

11. B.s. 1377; 1990. Method of determination of Organic Matter in aggregate. London P 213.

12. Dunn, I., Anderson, L. and kiefer, F. 1980. Fundamental of Geotechnical analysis, USA, John wiely\& sons inc., p 414.

13. Mecauley, A., Jones, C., and Rutz, K.O. 2017. Soil PH organic matter, MSU Extension, No.8, p. $1-16$.

14. Lambe, T. W. and whitman, R.V. 1969. Soil Mechanics, John wiley and Sons. Inc. New york, pp 553.

15. Baver, L.D. 1972. Soil Physics, 4th. Ed., John Wiley \& sons inc, New York, pp 498.

16. Earth Manual, E8 2004. Standard Specification for Materials of Test of Soluble solids salt of aggregate, Volume 4, p. 1-3. 